\title{
Bamulian: A Unique Sub-Himalayan Palaeolithic Culture of North India
}

\author{
Anek R Sankhyan* \\ Paleoanthropologist and Visiting Fellow, Anthropological Survey of India, Kolkata \& Dehradun, India
}

Submission: March 20, 2018; Published: April 04, 2018

*Corresponding author: Anek R Sankhyan, President, Palaeo Research Society, IPH Colony, Ghumarwin India, Email: arsankhyan@gmail.com

\begin{abstract}
Reported here is a unique and richest Acheulean site Bam-Tanda along the Sir Khad -a tributary of river Satluj flowing through Ghumarwin - Bilaspur area of Himachal Pradesh, north India. The indication of Acheulian was noted since 2010, but the magnitude of such findings could only be realized after having collected 402 tools in the fall of year 2017 and beginning of 2018. This site alone has the largest share of 300 Acheulian tools compared to 50 tools from Atabarpur (Punjab). Here, the handaxes (138) predominate the cleavers (77), and the spear and arrow projectiles (40) take over the choppers (34). For the first time the haftable adzes and hoes (26) were also discovered coupled with large and moderate sized sickles (2), saw-cutters (2) and chisels (2). The backed knives (18) and end-scrapers (14) are quite frequent as are the side and convergent scarpers (18). Three hitherto unknown 'Laurel Leaf'-kind of thin and large flake blade tools rather weapons add to the quality of the site. Another unique feature is occurrence of gigantic handaxes, cleavers and choppers attesting the might of their user. In view of such a diversity, richness and uniqueness of the site, it is christened as Bamulian, after the village Bam. The mighty Bamulian man ruled the SubHimalayan region for long from ca 0.5 to 0.05 million years ago, and pushed the tiny Soan Man deep into the Siwalik forests and Choes, and made him extinct or migrate elsewhere.
\end{abstract}

Keywords: Bam; Sir khad; Ghumarwin; Siwaliks; Acheulian; Diversity

\section{Introduction}

Ghumarwin-Bam in District Bilaspur of a north Indian state of Himachal Pradesh is a long intermountain depression (dun) between the Siwalik range in the west and the Sub-Himalayan mountains (dhar) in the east, such as the Tiun dhar at Ghumarwin and the Sikandra dhar fronting Bam. This dun is a northern extension of the Satluj valley, and drained by the Sir Khad, one of the six major tributaries of the river Satluj (= Sutlej or ancient Shatadru) flowing through District Bilaspur. The Sir Khad is, in turn, tributed by small streams, called Choe, originating from the uplifted Siwalik terrain. At Bam, the dun opens up as a vast alluvial fan due to the closure of the Siwalik range. Here, the Upper Siwalik Boulder Conglomerate Formation is tilted at $45^{\circ}$ $70^{\circ}$ westward. Consequently, deep gorges are formed and the Siwalik Choes tribute to bigger streams, like Drugh, that joins the Sir Khad down at Bam-Tanda-Kamlu-Salaown villages.

The Soanian man had his extensive domain in the larger duns, such as the Sirsa dun of Nalagarh-Baddi area [1-2] and Kangra-Beas-Banganga dun [3-4]. The Soanian occurrences were for the first time reported from Ghumarwin Siwalik forests and Choes by the author in 1979-1983 [5-6] at a number of places, such as at a rock-shelter east of Ghumarwin Court area at Tikri extending southward to Kiari and Tarontara, and northward to Chehad, Soyee and Baddu-Bhadrog villages. In the extreme north of Ghumarwin, the Soanian tools were found at Haritalyangar, Lehri Sarail (Mandal), Ladhyani, Bhapral-Badon Siwalik scarps and Choes. While looking for more Soanian tools in the year 2010, the author encountered for the first time large flake Acheulian cleavers and handaxes at Kallar -Balghad- at the confluence of Sir, Sukkar and Saryali khads with the Satluj. That brief exploratory work could not be pursued until 2014 when the author made a large collection of Acheulian picks, cleavers, handaxes, scraper, knives, tortoise cores, etc. along the course of the Sir Khad at Sunhani, Ghumarwin Bridge and Stadium, Baddu-Bhadrog, Kasohal and Padohri. But being away for two years he initiated fresh explorations after setting up the Palaeo Museum in mid 2017 and reported some of the findings [7]. But, a short visit to Kamlu-Tanda-Bam-Kotlu-Jahu and Mundkhar in November-December 2017 was encouraging and prompted a thorough exploration. This resulted in the accrual of large assemblages of 402 Acheulian tools. They are so varied and unique in typology and some hitherto unknown types from anywhere in north India;, including the only one large known site Atabarpur in Punjab having yielded 50 stone tools [8-11]. Hence, considering its richness and intensity, variety and uniqueness of the assemblages being reported here, the site is christened as Bamulian, after the village of Bam (Figures 1-6 Plates). 


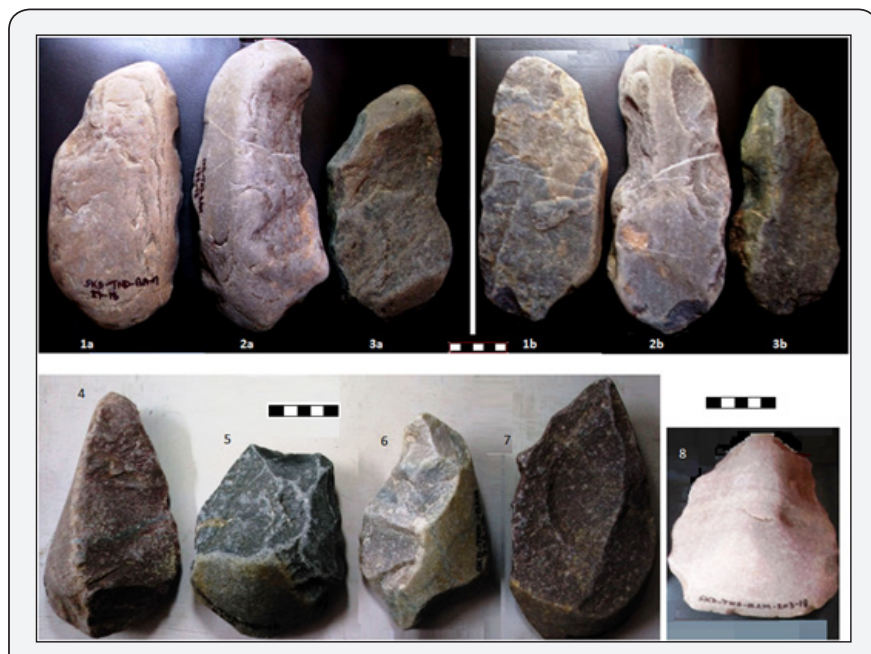

Figure 1: Plate 1-handaxes 1-8.

\section{Results}

\section{The stratigraphy and chronology of the Bam site}

At Bam-Tanda and elsewhere in Ghumarwin area, along the course of the Sir Khad, two aggradational terraces were observed. The topmost terrace is the piedmont zone of the SubHimalaya cut by the Sir Khad. Its' stone-tool containing section represents the first major aggradational terrace about 30 feet in thickness formed by the erosion of the uplifting/tilted Boulder Conglomerate Formation. A few in situ Acheulian tools were in the section but a number of them were lying at its base. It does differ in thickness due to wash out of the sediments, and at many places almost cut and washed out by Sir Khad. It is comprised of three main layers of the gravels, sands, silt, at time red clays too, and interspersed with boulders used for making tools.

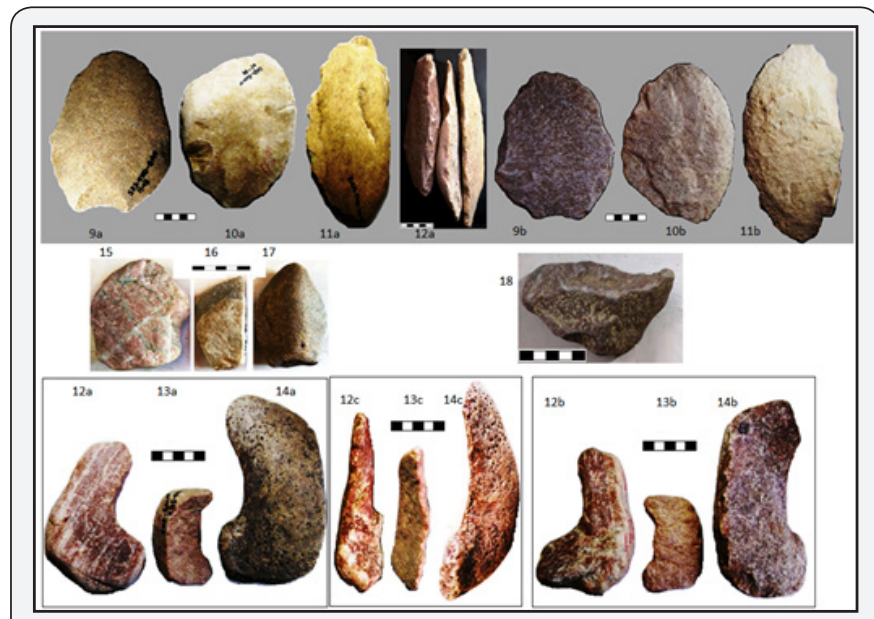

Figure 2 : Plate-2-Laurel Leaf, sickles-saw- chisels-awl.

Below this is the middle terrace, which could have been about 20 feet but has been gradually cut by the river in different phases, and therefore descended down gradually unto the recent channel bed. It forms the wide spacious Bam valley tableland and its top is sealed by a fertile alluvial soil, which was used by the farmers for growing paddy crop. But, since a couple of years, cropping is abandoned. At some points it forms 4-6 feet deep ditches which expose the stone-tool bearing layers of gravels, silts, pebbles and boulders. Its section is exposed along the recent Sir Khad channel bed and is richly implementiferous and is continuous with the vast channel bed comprised of huge boulders, which are overlooking the landscape, notably at confluence of Mundkhar Khad with the Sir Khad at Jahu. Due to sand and gravel mining most of the artifacts have been lost there. Fortunately for us, the Bam-Tanda Sir Khad site is little mined at present and therefore preserved the richness and diversity of the Acheulian industry. But, it will also be soon lost to mining as is its tributary Drugh here.

The tool-bearing Sir Khad boulder-cobble bed owes to Boulder Conglomerate Formation as a consequence of the rising Sub-Himalayan hills cut by the Sir Khad from time to time across the valley and longitudinally. So, the large Acheulian tools would post-date the Boulder Conglomerate Formation dated to about half a million years BP and may range from 0.5 to 0.05 million year BP. Archaeological lithic cultural traditions continued over time and may range from early Late Acheulian unto the Middle and early Upper Palaeolithic.

\section{Raw material and technique of flaking}

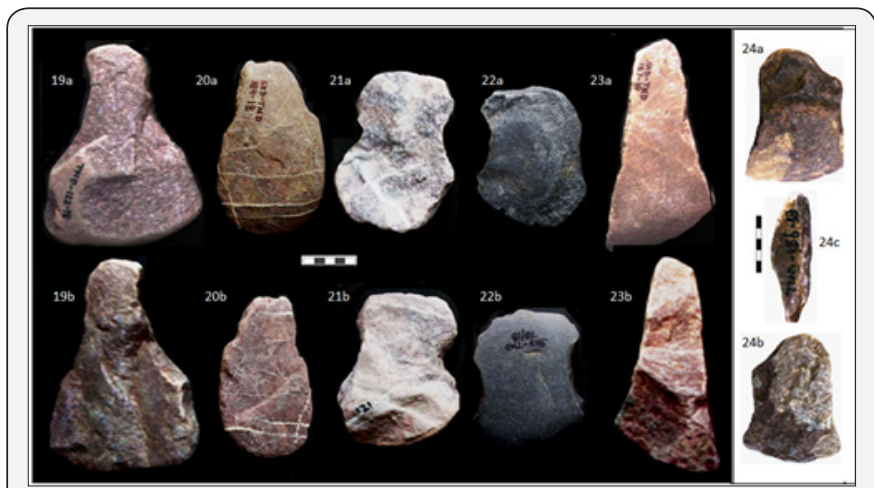

Figure 3 : Plate-3 hoes -axes (adzes).

The Bam-Ghumarwin artifacts are made on medium to coarse-grained quartzite cobbles and boulders of various hues, mainly light gray, ash gray, ash-brown chocolate, and ash black and black, and many are also on milky quartz. The quartzite is generally fined grained and highly metamorphosed. The toolmaker has intelligently chosen the cores and blanks and pre-planned the kind of tool he intended to make while taking advantage of the natural core surface. The shape of the boulders is selected in such a way that there is little need to flake the cortex and the unifacial flake handaxes present a bifacial core look. with minimum efforts. Most of such handaxes are unifacial in design but bifacial in appearance with least labor invested. This is also so because there is luxury of the raw material at the site. In true core biases the proximal part of the tool cortex is trimmed retaining the hind thick cortical butt. The toolmaker preferred long and ovate round hand axes trimmed at the circumference with minimum effort. The Kombewa core 
reduction technique is frequently employed for handaxes and cleavers to shed out the core burden. The Levalloisian broad and elongated tongue-like ventral face of the large and small flakes is also a common feature, where the striking platform is short or broad and internally angles at about $30^{\circ}$. In most of the cases the bulb of percussion is defused.

\section{The composition of the Bam -Ghumarwin archaeological assemblage}

Table 1: Types and per cent distribution of various tools at BamGhumarwin Sir Khad area.

\begin{tabular}{|c|c|c|c|}
\hline Sr. No. & Tool Type & Total & $\%$ \\
\hline 1 & Handaxes* & 138 & 34.3 \\
\hline 2 & Cleavers & 77 & 19.2 \\
\hline 3 & $\begin{array}{c}\text { Spears \& } \\
\text { Arrows }\end{array}$ & 40 & 10 \\
\hline 4 & Choppers & 34 & 8.5 \\
\hline 5 & Axes \& Hoes & 26 & 6.5 \\
\hline 6 & Scrapers & 18 & 4.5 \\
\hline 7 & Knives & 18 & 4.5 \\
\hline 8 & End Scrapers & 14 & 3.5 \\
\hline 8 & $\begin{array}{c}\text { Tortoise Cores } \\
\& \text { hammers }\end{array}$ & 14 & 3.5 \\
\hline 10 & Awls \& Notches & 7 & 1.7 \\
\hline 11 & Picks \& Drills & 7 & 1.7 \\
\hline 12 & Sickles \& Saws & 4 & 1.0 \\
\hline 13 & Laurel Leaf & 3 & 0.7 \\
\hline 14 & Chisels & 2 & 0.5 \\
\hline \multicolumn{2}{|c|}{ TOTAL } & 402 & \\
\hline
\end{tabular}

*Types of handaxes

Ovate $=51$, Pear $=29$, Almond $=20$, Chordate $=12$, Misc.$=16$

[Total $=138]$

$\mathrm{UF}=80(58 \%) ; \mathrm{BF}=58(42 \%)$

The size variation in handaxes

\begin{tabular}{|c|c|c|c|}
\hline \multicolumn{4}{|c|}{ The size variation in handaxes } \\
\hline Min $(\mathrm{m}) \max$ & Min $(\mathrm{m}) \max$ & Min $(\mathrm{m}) \max$ & Min $(\mathrm{m}) \max$ \\
\hline Length & Breadth & Thickness & Scars \\
\hline $\begin{array}{c}100(154.6) \\
288\end{array}$ & $33(109) 168$ & $16(48.9) 138$ & $5(24.3) 52$ \\
\hline
\end{tabular}

The typological classification and frequency data of the findings are presented in Table 1, and 41 tools are presented and figured in five photographic plates I-V. It may be noted that the tool assemblage from Ghumarwin-Bam-Tanda is characterized by a preponderance of the handaxes $(34.3 \%)$ over the cleavers (19.2\%) or Choppers (8.5\%). Interestingly, the spears and arrowhead points $(10 \%)$ overtake the Choppers $(8.5 \%)$. The $4^{\text {th }}$ place in order of frequency is occupied by the axes (or adzes) and hoes (6.5\%), which could be hafted and used like modern iron axes and spades. Such features are unique to the Bam-Tanda-Ghumarwin industry not seen the Atabarpur (Punjab) typical Acheulian industry, where cleavers are almost double than the handaxes, and the spears and arrows or axes and hoes are lacking. The bifacial choppers find greater representation compared to the unifacial ones and extensively trimmed compared to the small Soanian pebble choppers.

Out of over 450 stone tools, only 402 implements were catalogued, analyzed and reported here. It may be mentioned that the unstudied sample contains 12 handaxes,, four cleavers, one adz and one hoe. The Bam site alone has yielded 300 tools, excluding the untouched flakes and unfinished artifacts which were not sampled. Lots of artifacts were left in the site, but a team from Dehradun collected and took away most of them. Massive handaxes also form the part of the industry as are the cleavers as well as the choppers, only a few of them were sampled. On the sixth place in frequency are the scrapers of various kinds, followed closely by the knives. The end scrapers and tortoise cores occupy the next frequent category, followed by the awls and notches, picks and drills (borers). Very rare collection is that of three "Laurel Leaf" types of large elongated and ovoid thin flake handaxes or blades intensively retouched at margins.

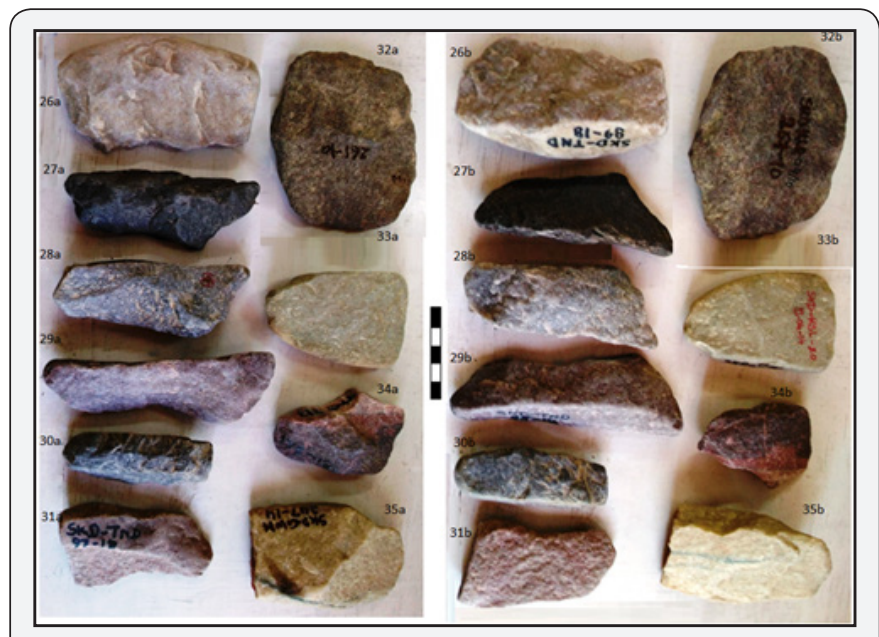

Figure 4 : Plate-4- backed knives, end scrapers-side scrapers.

Such tools have not been reported from Peninsular Indian sites including the central Narmada valley where the author has worked for about three decades and heaped over 9000 Acheulian artifacts and 1500 fossils housed at the Anthropological Survey of India, Kolkata.

The relative proportions of the tools could be relied upon as the site was hitherto unexplored and relatively undisturbed except by floods or a very recent sand mining in a little part of the site from where small artifacts were retrieved. The Table 1 also presents the metrical data on the maximum length, breadth and thickness of the 138 hand axes and their minimum, mean and maximum values useful for future comparative study with other similar sites. In addition, similar data on the number of flake scars present on the handaxes are added. They indicate 


\section{Global Journal of Archaeology \& Anthropology}

the intensity of labor put by the Bamulian man in making and shaping these implements.

The unique diversity of the Bamulian industry would be further analyzed to reflect on the various occupations adopted by the prehistoric man. Of course, the data reveal him as a very efficient hunter, who preferred the use of projectiles and bow and arrows from a distance besides direct close combat. The adzes and hoes, the sickles, saws, chisels mimic the modern iron tools, and the sophisticated "Laurel-Leaf" type are special large blade tools or weapons as local innovations. The diversity of the types reflects the diversity of various kinds of specialized occupations. They include earth work or soil processing for digging out the tubers and primeval plantation of certain food plants. The harvesting or cropping of plants is indicated by the sickles. Wood-cutting and wood-work is evident from the hafted axes or adzes, chisels and saw-cutters and large cleavers, etc. The Bamulians every likely made temporary huts and lived for long in the area. They likely practiced some sort of food production to supplement the animal flesh, which has been the primary food.

The present findings confirm the hypothesis [7] that the mighty Bamulian man of Ghumarwin-Bam Sir Khad area had captured the major rivers and the their surroundings and pushed the small-bodied Soan man deep into the interior of the Siwalik forests and Choes. Ghumarwin Sir Khad bridge and Stadium area has also been the favorite abode of both Acheulian and Soanian people, who might have some sort of competitive and symbiotic interactions which need to be explored further. There could have been many sites along the major river Satluj, which have since been sunk in the Govindsagar Lake backwaters of the BhakhraNangal dams in Bilaspur area. More exploratory work is needed in the upper reaches of the Satluj and Beas valleys to find out more sites as there is some indication from the Spiti valley [12] that the Acheulian hunter had also adventured into the higher reaches of the Himalayas. The present work is just a beginning and much research is need in Himachal Pradesh to unravel more secrets of this unique prehistoric culture, its expansion, routes of migration, bio-cultural evolution and contribution to modern human gene pool or causes extinction. The certain kinds of stone tools mentioned above suggest cultural continuity and that we have learnt much about the technology of these prehistoric people. A very rare painted pebble and an embryoshaped pendant was discovered from Ghumarwin Sir Khad area by the author [13] which give us indications of evolution of early portable art of the prehistoric man.

In passing, it may be mentioned that Ghumarwin-Haritalyangar Siwalik area has been previously world known for the fossil remains of the Late Miocene apes and hominids Sivapithecus, Gigantopithecus and Krishnapithecus [14-16]. However, the fossil remains of the Palaeolithic tool-maker are yet awaited from the area. They are so far recovered only from the Central Narmada valley in South Asia with a large share by the author to the contribution [17-22]. Future studies are contemplated to understand the bio-stratigraphy, chronology and paleoecology under the auspicious of Palaeo Research Society and the findings need to be deposited in the Palaeo Museum set up last year at Ghumarwin, where the fossil and present Palaeolithic material are housed.

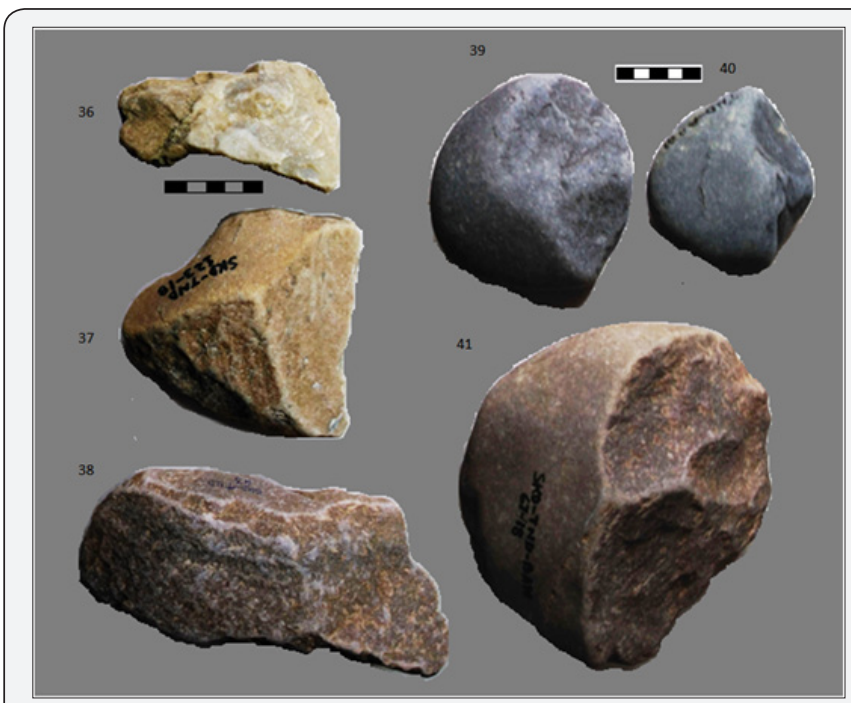

Figure 5 : Plate-5-few cleavers-choppers.

\section{References}

1. Sen D (1955) Nalagarh Palaeolithic culture. Man in India 35(3): 176183.

2. Sankhyan AR, Bhatia AK (1983) Report on the Nalagarh- Baddi area Soan implements. Anthropological Survey of India, Dehradun (unpublished report).

3. Lal BB (1956) Palaeoliths from the Beas and Banganga valleys, Punjab. Ancient India 12: 58-92.

4. Joshi RV (1979) Stone Age Environment and Cultural Sequence in the Kangra Valley, Himachal Pradesh. In: VC Ohri (Eds.), Prehistory of Himachal Pradesh, State Museum Simla, Department of Languages \& Culture, H.P p: 1-42.

5. Sankhyan AR (1979) The first evidence of early man from Haritalyangar area, Himachal Pradesh. Science and Culture 47: 358-359.

6. Sankhyan AR (1983) The first record of Early Stone Age tools of man from Ghumarwin, Himachal Pradesh. Current Science 52(3): 26.

7. Sankhyan AR (2017) Penetrance of Acheulian in the Soanian territory in Ghumarwin Siwalik area of Himachal Pradesh: A first report. International Journal of Current Research. 9 (12): 63737-63745.

8. Kumar M, Rishi KK (1986) Acheulian elements from Hoshiarpur region (Punjab). Man and Environment 10: 141-142.

9. Mohapatra GC, Singh M (1979) Prehistoric investigations in a subHimalayan valley, Himachal Pradesh, India. Current Anthropology 20(3): 600-602.

10. Mohapatra GC (1981) Acheulian discoveries in the Siwalik Frontal Range. Current Anthropology 22 (4): 433-435.

11. Gaillard C, Singh, Rishi KK (2008) Technological analysis of the Acheulian assemblage from Atbarapur in the Siwalik Range (Hoshiarpur District, Punjab). Man and Environment 33 (2): 1-14.

12. Chauhan H, Kumar S, Kumar N, Vanyal V ( 2017) Newly discovered Palaeoliths from the Spiti valley (Himachal Pradesh): A preliminary 
study. In Hari Chauhan (Eds.), Rediscovering Spiti: A historical and archaeological study. Himachal State Museum, Shimla p: 1-13.

13. Sankhyan AR (2017) Hitherto unknown Pleistocene portable art from India. International Journal of Current Research. 9(09): 57562-57566.

14. Simons EL, Chopra SRK (1969) Gigantopithecus (Pongidae, Hominoidea): A new species from Northern India. Postilla 138: 1-18.

15. Sankhyan AR (1985) Late occurrence of Sivapithecus in Indian Siwaliks. Journal of Human Evolution 14(1): 573-578.

16. Sankhyan AR, Kelley, J, Harrison T (2017) A highly derived Pliopithecoid from the Late Miocene of Haritalyangar, India. Journal of Human Evolution 105: 1-12.

17. Sonakia A (1984) The Skull Cap of Early Man and associated mammalian fauna from Narmada Valley Alluvium, Hoshangabad area MP (India) Records Geological Survey of India 113: 159-172.
18. Sankhyan AR (1997) Fossil clavicle of a Middle Pleistocene hominid from Central Narmada Valley. Journal of Human Evolution 32:3-16.

19. Sankhyan AR (2005) New fossils of Early Stone Age man from Central Narmada Valley. Current Science 88(5): 704-707.

20. Sankhyan AR, Dewangan LN, Chakraborty S, Prabha S, Kundu S, et al. (2012) New human fossils and associated findings from the Central Narmada Valley, India. Current Science 103(12): 1461-1469.

21. Sankhyan AR (2017) Pleistocene hominin fossil femora and humeri. International Journal of Anatomy and Research 4(1): 4510-4518.

22. Sankhyan AR (2017) First record and study of prehistoric sacra from central Narmada valley (M.P.). Int J Anat and Res 3(1): 4144-4151.

\section{Your next submission with Juniper Publishers} will reach you the below assets

- Quality Editorial service

- Swift Peer Review

- Reprints availability

- E-prints Service

- Manuscript Podcast for convenient understanding

- Global attainment for your research

- Manuscript accessibility in different formats

( Pdf, E-pub, Full Text, Audio)

- Unceasing customer service

Track the below URL for one-step submission https://juniperpublishers.com/online-submission.php 